\title{
When venture capitalists are attracted by the experienced
}

\author{
Dohyeon $\mathrm{Kim}^{*}{ }^{*}$ and Su Yong Lee
}

*Correspondence:

drkim@kookmin.ac.kr

Kookmin University, Seoul,

South Korea

\begin{abstract}
This article tries to find when the experience plays a key role in investment decisions by venture capitalists (VCs) investment decisions. First, we analyze the relative importance of the decision-making criteria that VCs have in mind. Then, the relationship between uncertainty and entrepreneurs' experience is investigated. The conjoint analysis and the multiple regression analysis model are applied to sets of hypothetical scenarios to assess the relative importance of the decision-making criteria of the 263 South Korean VCs. VCs generally value entrepreneurs' education and industry experience in making the investment decision. However, when uncertainty is very high, the newness of the product is high and the completeness of the product is low, VCs focus on entrepreneurs' managerial experience of entrepreneurs. These findings indicate that environmental uncertainty changes the relative importance of the $\mathrm{VC}$ investment criteria. Our research enhances the understanding of how VCs chose to invest, thus helping start-up companies receive VC funding and, ultimately, fostering the growth of highrisk-high-return companies.
\end{abstract}

Keywords: Venture capital investment, Entrepreneurial experience, Managerial experience, Uncertainty

\section{Introduction}

Startups are characterized by high returns and are high growth, and also key drivers of economic growth, because they lead to increased productivity, the creation of new jobs, and the promotion of corporate innovation and internationalization (Carayannis \& Rakhmatullin, 2014; Mason \& Brown, 2014; Santos et al., 2021). In particular, the introduction of innovation in various fields and the emergence of new industries, such as biotechnology, the Internet, medical information technology, and new materials industries, has largely been driven by startups, in which venture capitalists (VCs) play a significant role (Baum \& Silverman, 2004; Chang, 2004). Although startups need capital throughout the process of founding and growth, the high level of uncertainty, high-risk, and potentially high-reward business, leads to financing difficulties for venture companies (Gompers \& Lerner, 2001). Since entrepreneurs without evidence of performance or collateral have limited access to traditional financial institutions, such as banks, high-risk startups with high growth potential can instead acquire the necessary funding from VCs (Berger \& Udell, 1998). author(s) and the source, provide a link to the Creative Commons licence, and indicate if changes were made. The images or other third party material in this article are included in the article's Creative Commons licence, unless indicated otherwise in a credit line to the material. If material is not included in the article's Creative Commons licence and your intended use is not permitted by statutory regulation or exceeds the permitted use, you will need to obtain permission directly from the copyright holder. To view a copy of this licence, visit http:// creativecommons.org/licenses/by/4.0/. 
Studies of VC decision-making have initially derived from the question of startup success. VCs are investors who select startups with a high probability of success, so investigating VCs' investment decisions may provide a clue to understanding the key success factor of startups (Zacharakis \& Meyer, 2000). Accordingly, the main focus of previous studies was the decision-making process and the criteria of VCs in relation to the evaluation of venture companies (Hall \& Hofer, 1993).

Another complementary stream of VC research focuses on the factors that influence the relative weight and importance of decision-making criteria (Franke et al., 2008). The studies in this stream have generated some interesting insights. First, the human resources of the startup-the founder and the team, are the most valued in VCs' decision making (Muzyka et al., 1996; Silva, 2004). Second, the level of uncertainty regarding products, services, the market, and the industry affect VCs' decisions (Kollmann \& Kuckertz, 2010). However, little is known about how the uncertainty and human resources interact with VCs' decisions. This paper stems from here; its purpose is to investigate the importance of the entrepreneur's human and social resources in VCs' investment decision making and understand the relative combined importance of uncertainty and the experiential factors of entrepreneurs based on human capital theory and social capital theory. We utilize a conjoint analysis (Shepherd et al., 2003), which enables experiments on the mutual influence of entrepreneurs' experiences and uncertainties on the decision-making process of VCs. The sample of this study consists of 263 Korean $\mathrm{VCs}$, the largest number in $\mathrm{VC}$ decision-making studies to date.

This paper proceeds as follows. After reviewing extant knowledge about VCs' investment decisions, the paper introduces uncertainty as a theoretical concept. Then it explores the relationship between the experience and uncertainty. Next, this article presents the methodology and results of an experimental study among 263 VCs in South Korea. Finally, the findings and theoretical and practical implications are illustrated.

\section{Theoretical background}

\section{VCs' decision making}

Since VCs aim to generate high profitability by investing in high-risk ventures (Berger \& Udell, 1998), they collect information about ventures and entrepreneurs and make decisions using a multi-step process for making the best choice (Silva, 2004). Several studies have focused on the decision-making process through the use of various models. All of those models share one element-the multi-step decision making (Silva, 2004).

Tyebjee and Bruno (1984a) proposed the basic structure of the investment decisionmaking process as a five-step model: (1) the deal origination stage that discovers a potential venture; (2) a deal screening stage to review proposals in technology, market products, and scope; (3) a deal evaluation stage to evaluate and analyze the business plan; (4) a deal structuring stage in which investment terms are negotiated and transactions are clarified; and (5) a post-investment activity stage that prepares for the future exit (initial public offering or sale) by supporting the management of the company's portfolio and adding to its value.

In early studies, the VCs' decision-making process was characterized by a small number of steps (Fried \& Hisrich, 1994; Tyebjee \& Bruno, 1984b). However, as the environment surrounding ventures becomes more complex, innovation and risk increase, the 
decision-making process was divided into more complex steps, of which the names and numbers vary among scholars (Boocock \& Woods, 1997).

Alongside VCs' decision-making process, the criteria VCs apply to select companies to invest in has also received constant attention (Andrieu, 2013; Woods et al., 2020). It is well-known that VCs' decisions are difficult due to the significant information asymmetry that exists between VCs and entrepreneurial firms without observable track records (Kollmann \& Kuckertz, 2010). To cope with information asymmetry, VCs utilize various investment criteria, some of which are tacit and not codified. Studies of decision-making criteria are important not only from an academic perspective but also from a practical perspective, for they could help startups to secure funding, which is the most important determinant of venture performance (Chrisman et al., 1998). They could also help VCs make better decisions (Hall \& Hofer, 1993; Zacharakis \& Meyer, 2000).

VCs invest based on the human and social capital of the entrepreneur, as well as the technological and market potential of the proposed products (Zacharakis \& Shepherd, 2005). Beim and Lévesque (2004) suggested that VCs consider a wide range of criteria during the valuation process, including the quality of business management, product uniqueness, market opportunity, and the potential for increasing the value of the ventures. The criteria that influence the decision-making of VCs can be categorized into five groups: (1) characteristics of the entrepreneurial team, such as management skills and experience (Hsu, 2007; Miloud et al., 2012); (2) characteristics of the products, such as their newness and completeness (Macmillan et al., 1985); (3) market/industry characteristics, such as market growth and market size for products (Mason \& Stark, 2004; Zutshi et al., 1999); (4) financial characteristics, such as expected returns and payback periods for invested funds (Muzyka et al., 1996); and (5) additional criteria, such as deal factors, network effects and geographical location (Boocock \& Woods, 1997; Miloud et al., 2012).

However, there is no agreement among scholars on the relative importance or weight of these criteria. A few recent studies have emphasized the characteristics of entrepreneurs as a decisive factor in VCs' decision making (Muzyka et al., 1996). Since VCs invest in high-risk startup companies, they pay more attention to the characteristics of the entrepreneurs than to uncertain external environmental characteristic. In a similar vein, Vinig and De Haan (2005) found that in the US, VCs regarded certain criteria related to entrepreneurs' characteristics, such as track record, leadership skills, and knowledge of the market and industry, as the most important. Silva (2004) noted that in Portugal, the primary focus was to evaluate entrepreneurs' qualities of the entrepreneurs during the investment decision-making process, such as their personal and professional characteristics and their commitment to the business idea. Furthermore, experience was found to be the most important factor, suggesting that financial considerations were not a priority in the evaluation process.

However, there are some contradictory results. Mason and Stark (2004) compare the importance of decision-making criteria by dividing investors into VCs, bank experts, and angels in the south of England. The results of the study show that VCs give a low ranking to the characteristics of entrepreneurs in decision making and concluded that they placed greater emphasis on market characteristics and financial considerations. In an 11-year longitudinal data set from a European-based VC firm, Petty and Gruber 
(2011) found that the characteristics of the product or service and the characteristics of the market were considered important decision criteria when rejecting investment in a startup company. These studies show contradictory results from previous articles stating that entrepreneurial characteristics are the most important investment criteria.

To shed new light on these controversies, the study attempts to determine whether the characteristics of entrepreneurs are highly valued in $\mathrm{VC}$ decision making.

\section{VCs' decision making and entrepreneurs' experience}

As reviewed in the previous section, many studies found that VCs invest in entrepreneurs. However, there is little research on how entrepreneurs' characteristics affect VC investment decisions of $\mathrm{VC}$, which is the focus of this study.

Human capital theory was developed to determine the income distribution of workers and the value of an investment in human resources. Individuals with higher levels of knowledge, skills, and other competencies produce higher performance outcomes than those with lower levels (Ployhart \& Moliterno, 2011). Similarly, the elements of the human capital of entrepreneurs, such as education, experience, knowledge, and skills increase entrepreneurial alertness, which prepares them to discover specific opportunities that others cannot see (Shane \& Venkataraman, 2000) and is the essence of the entrepreneurial process (Marvel, 2013; Vuong et al., 2015). Therefore, it is argued that human capital has a positive impact on entrepreneurial success by helping in planning and establishing strategies (Robert Baum et al., 2001). In addition, human capital facilitates the acquisition of resources, such as financial capital, that are essential for the establishment and operation of venture companies (Wiklund \& Shepherd, 2008). Human capital is also a source of financial capital (Chandler \& Hanks, 1998). Therefore, human capital is an important decision criterion that VCs use most frequently when evaluating the potential performance of venture companies (Zacharakis \& Meyer, 2000).

Social capital is defined as the sum of all the resources available to a person or organization through a social network (Sanchez-Famoso et al., 2014). It includes embedded resources from the bonds between individuals, communities, networks, and societies (Nahapiet \& Ghoshal, 2009), in contrast to human capital, which exists only in individuals as the accumulation of expertise. Social capital enables the identification of entrepreneurial opportunities (Bhagavatula et al., 2010), mobilizes resources (Batjargal, 2003a; Lechner et al., 2015), and can help external stakeholders establish the legitimacy of the firm (Elfring \& Hulsink, 2003). Social capital creates links with external networks to strengthen the trust of internal organizations through the connections of network members' connections and provides resources needed by the organization (Adler \& Kwon, 2002). A wide range of social networks will help entrepreneurs utilize their knowledge and resources. Furthermore, social capital increases the likelihood of success (Batjargal, 2003b), underpins the competitive advantage, and improves the survival rate (Singh et al., 1986) of entrepreneurial firms.

\section{VCs' decision making under uncertainty}

VCs face difficulties in decision making due to severe information asymmetry with respect to venture firms (Baum \& Silverman, 2004). While VCs should efficiently identify firms suitable for investment by examining the possibilities of the firm (Kirsch et al., 
2009), they have challenges related to constraints, biases, and heterogeneity of available information in the decision-making process (Zacharakis \& Shepherd, 2001). As found in behavioral decision theory, VCs rely on heuristics and bias owing to their bounded rationality either by limited alternatives or information and resources (Simon, 1955). Scholars found that the accuracy of decision is often limited by overconfidence (Zacharakis \& Shepherd, 2001), and similarity bias with which VCs prefer entrepreneurs with similar backgrounds (Franke et al., 2008).

The most difficult challenge for VCs is that the entrepreneurial firms to invest in are in their early stages, meaning that the organizational resources, activities, and business models of the firms are premature and liquid (Petkova et al., 2013). Baum and Silverman (2004) found VCs often pay high investment costs by failing in the prediction of the early stage startups and missing crucial investment opportunities. Amit et al. (1998) argue that uncertainty also stems from information asymmetry between the two parties. However, uncertainty may derive from the nature of entrepreneurial firms. For example, the newness of the firms' products is the source of uncertainty. Since the products (or services) are not yet in the market, whether new markets are formed and products are accepted involves a high level of uncertainty. Interestingly enough, whether the newness of products is beneficial to the firm is a venue of dispute. Although some studies positively demonstrate the relationship between products newness and market performance (Calantone et al., 2003), other scholars found a U-shaped relationship (Cooper \& Kleinschmidt, 1991), reverse U-shaped relationship (Goldenberg et al., 2001), or more complex relationship (Steenkamp \& Gielens, 2003) relationship.

The degree to which a venture's products have been developed also serves as an uncertainty factor. Audretsch et al. (2012) argue that entrepreneurial firms are more likely to receive investments from VCs if their products and prototypes thereof are patented. As the degree of development of the venture's products approaches the completion stage, the uncertainty of the investment is reduced, and the possibility of investment may be increased.

In this study, we focus on the uncertainty at the level of product newness and the degree of development of the product.

Figure 1 shows representative articles discussed above, and the flow of research.

\section{Research objective, methodology and data}

The purpose of this study is to empirically verify the effect of the newness and readiness of products, on the relative importance of the experiences of founders in venture capitalists' decision-making. Conjoint analysis is applied to a hypothetical scenario to assess the importance and priority of venture capitalists' decision-making criteria. Then, the relationship between the uncertainties of venture companies' uncertainties (in terms of the newness and completeness of products and services) and the relative importance of the decision-making criteria of venture capitalists is analyzed.

\section{Uncertainty and entrepreneurs' industry experience}

As discussed, the most important criteria VCs use in the investment decision-making process are the expertise and experience of entrepreneurs (Franke et al., 2008; Muzyka et al., 1996). Industry experience tends to increase awareness of industry trends and 


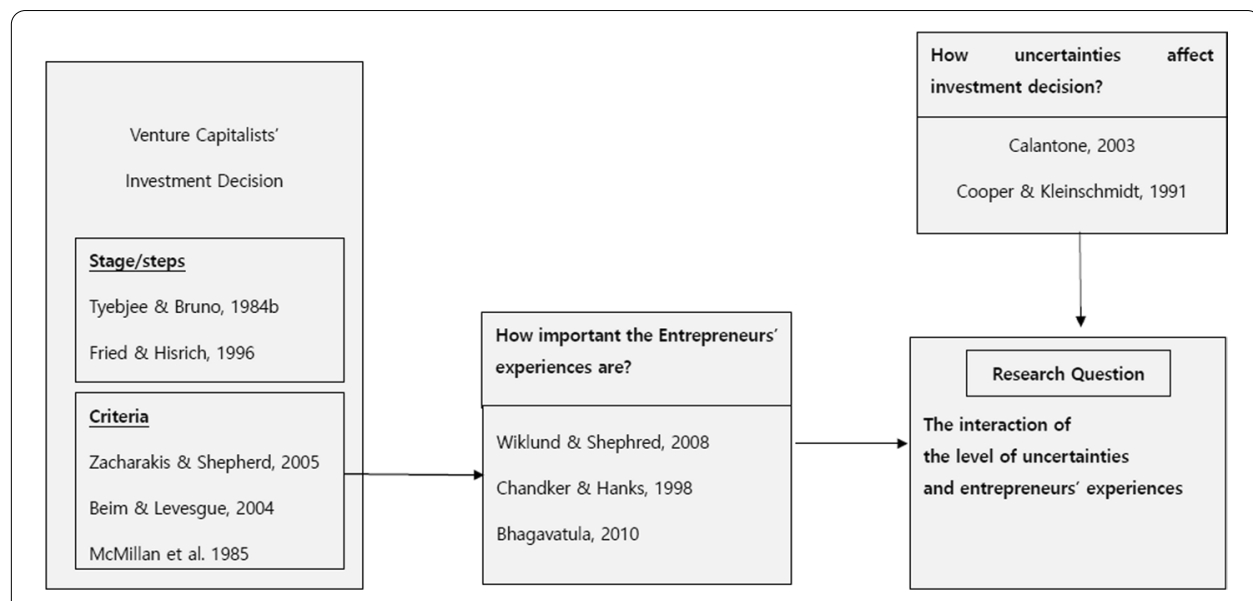

Fig. 1 Key extant studies leading to the research question

business opportunities. Therefore, the industry experience of entrepreneurs reduces risk and uncertainty and eventually affects the survival rate and turnover of startups (Delmar \& Shane, 2006). Studies have found that entrepreneurs with industry experience are better at assessing opportunities within the industry (Cassar, 2014), which positively correlates with VCs' valuations (Dimov \& Milanov, 2010). VCs believe that the founder's industry experience would help the firm's survival and consider it as one of the most important decision-making criteria (Franke et al., 2008). We suggest that VCs may place more value on the industry of entrepreneurs in cases of severe uncertainty. When a product is novel and far from completion, entrepreneurs should remain alert to changes in the industry, for which industry experience is very useful.

Hypothesis 1 The higher the uncertainty-the newer the products are, and the lower the completeness of the products, the more VCs consider the industry experience of entrepreneurs.

\section{Uncertainty and the entrepreneurs' managerial experience}

Managerial experience is a set of skills and knowledge about management practices that are crucial in making decisions about the operations of a company and defining a long-term strategy (Shane, 2003). Managerial experience is acquired in a management position by studying the processes within an organization and understanding the organization's routines in management-related decision making (Cooper et al., 1994). Through managerial experience, entrepreneurs can develop the ability to prioritize ideas and actions (Gifford, 1992). Experience not only strengthens the network and reputation of entrepreneurs, but it can also be applied to innovatively use firm resources (Parker, 2009).

Entrepreneurs with managerial experience have the cognitive frame and capacity to absorb knowledge from their environment (Eisenhardt, 1989), thus making them aware of the activities that must be done according to the company's circumstances. Gimeno et al. (1997) found that managerial experience, such as team management and 
management within a firm, was significantly and positively related to return on investment. In other words, when investors make investment decisions, firms found by entrepreneurs with substantial managerial experience have a higher value than those found by entrepreneurs without managerial experience (Miloud et al., 2012). When VCs have confidence in the entrepreneurs, the chance of investment increases, even without enough confidence in the firm itself (Payne et al., 2009).

Therefore, we suggest that VCs may resort more to managerial experience with greater uncertainty.

Hypothesis 2 The higher the uncertainty-the newer the products are, and the lower the completeness of the products, the more VCs consider the managerial experience of entrepreneurs.

\section{Uncertainty and educational background of the entrepreneurs}

From a cognitive perspective, individuals with a high level of academic ability can quickly recognize and identify complex phenomena and have an excellent ability to process information (Wally \& Baum, 1994). Individuals with a high level of academic achievement also have an innovative tendency (Wiersema \& Bantel, 1992) and are wellformed in cooperative relationships with others (Palmer \& Barber, 2001).

The educational background-also an element of human capital, may also create social capital. Entrepreneurs with a high level of education tend to form external social networks and develop social capital. Education received from prestigious universities is considered high social capital by itself (Lechner \& Dowling, 2003), as the socially embedded network links of founders constitute an important resource base (Belliveau et al., 1996).

There are a few studies linking the academic achievement of entrepreneurs to the financial performance of the entrepreneurial firms (Birley \& Norburn, 1987). A venture founded by a scholar has a high survival rate (Criaco et al., 2014) and is likely to hire new employees to create more jobs, apply for a patent, and conclude a contract (Siegel \& Wessner, 2012). According to Hsu (2004), a high level of academic achievement (e.g., a doctoral degree) among entrepreneurs has a positive effect on the evaluation of ventures in Internet-related industries. Therefore, we hypothesized that the educational background of entrepreneurs will be an important criterion in $\mathrm{VCs}$ ' decision-making process.

Hypothesis 3 The higher the uncertainty - the newer the products are, and the lower the completeness of the products, the more VCs consider the educational background of the entrepreneurs.

\section{Methodology}

To investigate the relative importance and priority of investment decision-making criteria, a five-step process has been developed. The five steps are, according to (Shepherd \& Zacharakis, 1999), to (1) select attributes and levels; (2) develop decision-making scenarios; (3) choose samples; (4) conduct an experiment; and (5) analyze data, as illustrated in Fig. 2. 


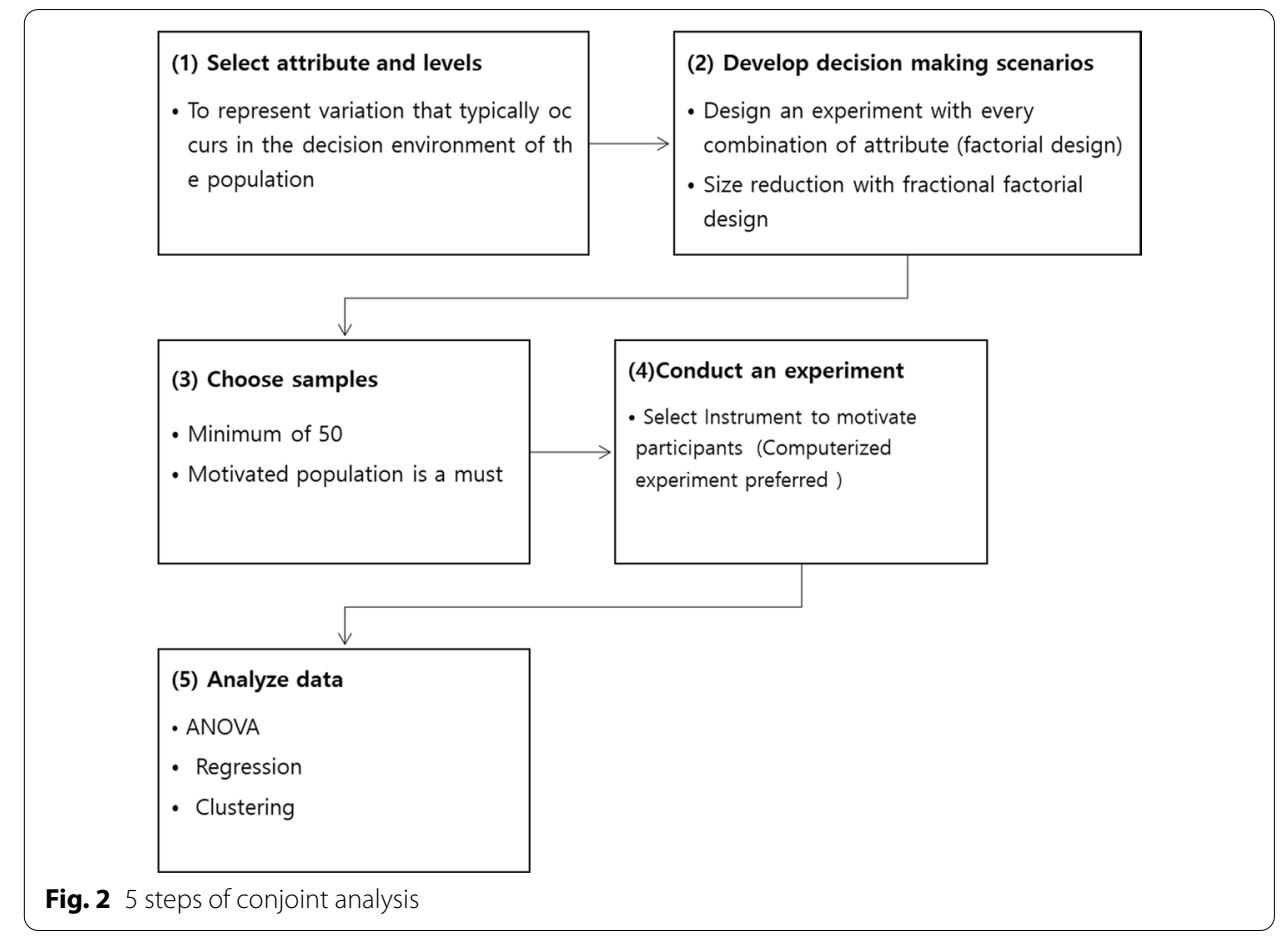

The experiment is designed for conjoint analysis. The results of the experiment are also analyzed with a multiple linear regression analysis, which illustrates the relationship between the uncertainties of the venture's products and the importance of entrepreneurial experience.

Conjoint analysis is an analytical method that requires respondents to form a series of judgments based on attributes. Its purpose is to investigate the basic structure of the cognitive systems (Shepherd \& Zacharakis, 1999). In this analysis, the general preferences for the various attributes presented can be examined to determine the relative value and importance of the individual attributes for the respondents. The Choice-Based Conjoint $(\mathrm{CBC})$ method adopted in this paper is an experimental method to select one of the alternatives given in a hypothetical scenario constructed by experimental design. The key advantage of this method is that the respondent makes decisions in an environment similar to that in which he/she would make actual decisions (Natter \& Feurstein, 2002). The validation and accuracy of predictions made this way are higher than those of traditional conjoint ranking at the individual level (Karniouchina et al., 2009).

This paper focuses on the VCs decision criteria used in the preliminary screening stage. In the screening stage, VCs make decisions mostly based on the business plan of the ventures. Therefore, the decision making at this stage is relatively similar to the decision making in conjoint analysis (Franke et al., 2008).

To measure the entrepreneurs' experiences and the uncertainty concerning the product's newness and completeness-the concepts in this study-a focus group interview was conducted with seven VCs. Subsequently, a set of questionnaires was administered to reflect another group of experts-10 VCs and professors. Through this process, seven attributes were defined to describe the experience of the entrepreneurs and uncertainty concerning the products, as well as their correlating levels to be used in the conjoint 
analysis. After determining the attributes of the analysis, the operational definition was made in a way that the level belonging to each attribute could be coded in the conjoint analysis. For example, the period of industrial experience of the founder can be known in the process of reviewing the business plan, but it is difficult to assess the level of industrial experience that the founder possesses. Therefore, the level was operationally defined in a way that can be measured quantitatively by expressing industrial experience as an objective and quantitative characteristic rather than a subjective and ambiguous method of expression, such as 'the founder has a lot or little industrial experience'. In this process, it was divided into two or three levels according to the characteristics of the attributes. The level for each attribute was determined through discussions and interviews with an expert group at FGI. The operational definitions are shown in Table 1.

\section{Sample and data}

This study is conducted with Korean VCs. Korea has the characteristics of being a very active country in VC investment, such as not only having the highest VC investment as a percentage of GDP among major countries, but also possessing the largest number of unicorns outside the US and China. In addition, compared to the vitalization of the VC industry, the number of VCs was relatively small, so the number of VCs at the time of the study was only about 600 . Therefore, it can be said that it is a very attractive country in that it can study the meaningful ratio of VCs in a specific country.

The survey was conducted using a web-based conjoint analysis by sending email with the URL address for the survey. Respondents were presented with an alternative combination of several attributes from the survey site linked in the e-mail and chose the most preferred combination of these attributes. We sent e-mails to 400 randomly selected VCs registered in the Korean Venture Capital Association, and ultimately received responses from $263 \mathrm{VCs}$ (response rate 65.3\%). The 263 responses were collected and used in the final analysis. It is worth emphasizing that the size of the respondents is quite large compared to the existing VC studies (Franke et al., 2008; Gompers et al., 2020; Rin et al., 2013). Table 2 summarizes the sample demographics.

\section{Results and discussion}

\section{The relative importance of decision-making criteria: a conjoint analysis}

In conjoint analysis, the relative importance is the ratio of the importance occupied by an attribute within the entire attribute, and the sum is 100. Part-worth is the respondent's relative preference for the level of attribute, and the sum is 0 (Shepherd \& Zacharakis, 1999). The higher the importance value (\%) of an attribute, the higher the preference of the respondent. Therefore, it can be understood that attributes with high importance values (\%) are decision criteria that VCs consider to be more important in decision making. The highest part-worth of a level within an attribute indicates that the level is more favorable than the other levels. The analysis shows that the educational background of entrepreneurs is the most important decision criterion for VCs by $22.44 \%$. The relative importance of other decision criteria is industry experience (19.24\%), newness of product (14.04\%), completeness of product (13.55\%), entrepreneurial experience (12.60\%), and experience in attracting investment (11.64\%). The managerial experience of entrepreneurs $(6.49 \%)$ was found to be the least important decision criterion. These results 
Table 1 Operational definitions and references

\begin{tabular}{|c|c|c|c|}
\hline Attribute & Levels & Operational definitions & References \\
\hline \multirow[t]{3}{*}{$\begin{array}{l}\text { Industry experience of the } \\
\text { entrepreneur }\end{array}$} & High & $\begin{array}{l}\text { The entrepreneur has more } \\
\text { than } 5 \text { years of experience in } \\
\text { the related industry }\end{array}$ & $\begin{array}{l}\text { Miloud et al., (2012), Zacharakis } \\
\text { and Shepherd (2001) }\end{array}$ \\
\hline & Moderate & $\begin{array}{l}\text { The entrepreneur has less than } \\
5 \text { years of experience in the } \\
\text { related industry }\end{array}$ & \\
\hline & Low & $\begin{array}{l}\text { The entrepreneur has no expe- } \\
\text { rience in the related industry }\end{array}$ & \\
\hline \multirow[t]{2}{*}{$\begin{array}{l}\text { Managerial experience of the } \\
\text { entrepreneur }\end{array}$} & High & $\begin{array}{l}\text { The entrepreneur has previous } \\
\text { managerial experience at least } \\
\text { as a team leader in a corpora- } \\
\text { tion }\end{array}$ & $\begin{array}{l}\text { Muzyka et al. (1996), Miloud et al. } \\
\text { (2012), Shane (2003) }\end{array}$ \\
\hline & Low & $\begin{array}{l}\text { The entrepreneur has no } \\
\text { managerial experience in a } \\
\text { corporation }\end{array}$ & \\
\hline \multirow[t]{3}{*}{$\begin{array}{l}\text { Entrepreneurial experience of } \\
\text { the entrepreneur }\end{array}$} & High & $\begin{array}{l}\text { The entrepreneur has } \\
\text { significant experience in the } \\
\text { establishment of a startup }\end{array}$ & Hsu (2007), Miloud et al. (2012) \\
\hline & Moderate & $\begin{array}{l}\text { The entrepreneur has experi- } \\
\text { ence in the establishment of a } \\
\text { startup }\end{array}$ & \\
\hline & Low & $\begin{array}{l}\text { The entrepreneur has no expe- } \\
\text { rience in establishing a startup }\end{array}$ & \\
\hline \multirow[t]{2}{*}{$\begin{array}{l}\text { Educational background of } \\
\text { the entrepreneur (degree and } \\
\text { university prestige) }\end{array}$} & High & $\begin{array}{l}\text { The entrepreneur has a doctor- } \\
\text { ate degree from a prestigious } \\
\text { university } \\
\text { The entrepreneur has a bach- } \\
\text { elor's degree from a prestigious } \\
\text { university } \\
\text { The entrepreneur has a doctor- } \\
\text { ate degree from a non-prestig- } \\
\text { ious university }\end{array}$ & Hsu (2007) \\
\hline & Low & $\begin{array}{l}\text { The entrepreneur has a } \\
\text { bachelor's degree from a non- } \\
\text { prestigious university }\end{array}$ & \\
\hline \multirow[t]{3}{*}{$\begin{array}{l}\text { Entrepreneur's experience in } \\
\text { attracting investment }\end{array}$} & High & $\begin{array}{l}\text { The entrepreneur has experi- } \\
\text { ence in receiving investment } \\
\text { from formal investors }\end{array}$ & Drover et al. (2017), Hsu (2007) \\
\hline & Moderate & $\begin{array}{l}\text { The entrepreneur has experi- } \\
\text { ence in receiving investment } \\
\text { from informal investors }\end{array}$ & \\
\hline & Low & $\begin{array}{l}\text { The entrepreneur does not } \\
\text { have experience receiving } \\
\text { investment }\end{array}$ & \\
\hline \multirow[t]{3}{*}{ Product (or service) newness } & High & $\begin{array}{l}\text { There are no products (or } \\
\text { services) in overseas markets or } \\
\text { domestic markets }\end{array}$ & Hyytinen et al. (2015) \\
\hline & Moderate & $\begin{array}{l}\text { There are products (or services) } \\
\text { in overseas markets, but not in } \\
\text { domestic markets }\end{array}$ & \\
\hline & Low & $\begin{array}{l}\text { There are products (or services) } \\
\text { both overseas and domestically }\end{array}$ & \\
\hline \multirow[t]{2}{*}{$\begin{array}{l}\text { Product (or service) complete- } \\
\text { ness }\end{array}$} & High & $\begin{array}{l}\text { Products (or services) are ready } \\
\text { to be launched in the market }\end{array}$ & Macmillan et al. (1985) \\
\hline & Low & $\begin{array}{l}\text { Products (or services) are under } \\
\text { development }\end{array}$ & \\
\hline
\end{tabular}


Table 2 Sample demographics

\begin{tabular}{|c|c|c|c|}
\hline Division & Frequency & Division & Frequency \\
\hline Gender & & Industry experience & \\
\hline Male & 243 & Technology Plan & 35 \\
\hline Female & 20 & $R \& D$ & 80 \\
\hline \multicolumn{4}{|l|}{ Age } \\
\hline Under the age of 35 & 18 & Production Management & 3 \\
\hline Age $35-$ under the age of 40 & 52 & Sales and Marketing & 24 \\
\hline Age $40-$ under the age of 45 & 54 & Management & 17 \\
\hline Age $45-$ under the age of 50 & 77 & Finance & 64 \\
\hline Age $50-$ under the age of 55 & 49 & Accounting & 8 \\
\hline Over the age of 55 & 13 & Other & 32 \\
\hline Field of examination & & Years of experience & \\
\hline Less than 3 years & 24 & \multirow{3}{*}{$\begin{array}{l}\text { ICT manufacturing/Manufacturing/ } \\
\text { Chemical/Material/Electricity/Machinery/ } \\
\text { Equipment }\end{array}$} & \multirow[t]{3}{*}{120} \\
\hline $3-<5$ years & 35 & & \\
\hline $5-<10$ years & 69 & & \\
\hline $10-<15$ years & 42 & IT Service/Distribution Service & 68 \\
\hline \multirow[t]{2}{*}{$15-<20$ years } & 73 & Bio/Medical & 52 \\
\hline & & Game/Digital Content & 12 \\
\hline \multirow[t]{2}{*}{ Over 20 years } & 20 & Visual/Performance/Record & 2 \\
\hline & & Others & 7 \\
\hline Degree possessed & & Startup experience & \\
\hline Bachelor's & 113 & Absence & 220 \\
\hline Master's & 124 & & \\
\hline \multirow[t]{2}{*}{ Doctor's } & 26 & Presence & 43 \\
\hline & 263 & & 263 \\
\hline
\end{tabular}

are consistent with previous research that suggests that the strong human capital of entrepreneurs, such as degrees from higher education institutions, has a positive impact on corporate success and is, therefore, an important criterion in VCs' decision making (Hsu, 2007). Table 3 summarizes the results of the conjoint analysis, showing the importance of the attributes and the part-worth value of each level.

\section{Entrepreneurs' experience under uncertainty}

To analyze the importance of entrepreneurs' experiences under uncertainty, a multiple linear regression is conducted with the results of conjoint analysis.

\section{Dependent variable}

To test the suggested hypotheses, dependent variables are selected as follows: (1) the importance of the industry experience; (2) the importance of the managerial experience; and (3) the importance of the educational background of entrepreneurs (degree and university prestige).

\section{Independent and control variables}

Uncertainty can be used as an independent variable. As discussed earlier, uncertainty is high when: 
Table 3 Results of the conjoint analysis

\begin{tabular}{|c|c|c|c|c|}
\hline Attribute & Level & Part-worth & SD & $\begin{array}{l}\text { Relative } \\
\text { importance } \\
\text { (\%) }\end{array}$ \\
\hline \multirow[t]{3}{*}{ Industry experience of the entrepreneurs } & High & 25.467 & 21.339 & 19.24 \\
\hline & Moderate & -1.021 & 12.871 & \\
\hline & Low & -24.447 & 21.63 & \\
\hline \multirow[t]{3}{*}{ Startup experience of the entrepreneurs } & High & 8.097 & 17.462 & 12.60 \\
\hline & Moderate & 4.982 & 12.147 & \\
\hline & Low & -13.079 & 14.058 & \\
\hline \multirow{4}{*}{$\begin{array}{l}\text { Educational background of entrepreneurs (degree and } \\
\text { university prestige) }\end{array}$} & High & 18.355 & 19.988 & 22.44 \\
\hline & & 16.266 & 22.481 & \\
\hline & & -21.727 & 20.606 & \\
\hline & Low & -12.894 & 22.442 & \\
\hline \multirow[t]{2}{*}{ Managerial experience of the entrepreneurs } & High & 7.503 & 8.125 & 6.49 \\
\hline & Low & -7.503 & 8.125 & \\
\hline \multirow[t]{3}{*}{ Entrepreneurs' experience in attracting investments } & High & 9.068 & 15.538 & 11.64 \\
\hline & Moderate & -1.445 & 13.454 & \\
\hline & Low & -7.622 & 15.769 & \\
\hline \multirow[t]{3}{*}{ Newness of product } & High & 0.629 & 21.242 & 14.04 \\
\hline & Moderate & 9.506 & 13.479 & \\
\hline & Low & -10.135 & 19.478 & \\
\hline \multirow[t]{3}{*}{ Completeness of product } & High & -17.332 & 17.365 & 13.55 \\
\hline & Low & 17.332 & 17.365 & \\
\hline & & & & 100 \\
\hline
\end{tabular}

SD Standard deviation

Newness of the product is high.

Completeness of the product is low.

We control the sex, age, investment field of VCs, degree obtained, industry experience before VCs, total experience as VCs, and prior entrepreneurial experience of VCs.

\section{Results of the regression and discussion}

The regression results are depicted in Table 4. First, we tested the hypothesis that VCs would regard entrepreneurs' experience as important when uncertainty is high-where the level of products completeness is low, and the newness of products is high. The results showed that newness $(t=0.1 .358, p>0.05)$ and completeness $(t=0.348, p>0.05)$ were statistically insignificant in relation to the importance of entrepreneurs' industry experience. The results of our conjoint analysis are consistent with the existing research that the entrepreneur's industrial experience is a factor that positively affects the survival and performance of ventures, so it is an important criterion for investment decisions of VCs (Franke et al., 2008). However, the results of regression analysis indicate that VCs do NOT consider more the importance of the entrepreneur's industry experience under uncertainties related to the product. Therefore, Hypotheses 1 was rejected.

In terms of entrepreneurs' managerial experience, the effect of uncertainty on the importance of managerial experience in VC decision was statistically significant for both newness $(t=2.760, p<0.01)$ and completeness $(t=0.5 .349, p<0.01)$. In the conjoint 


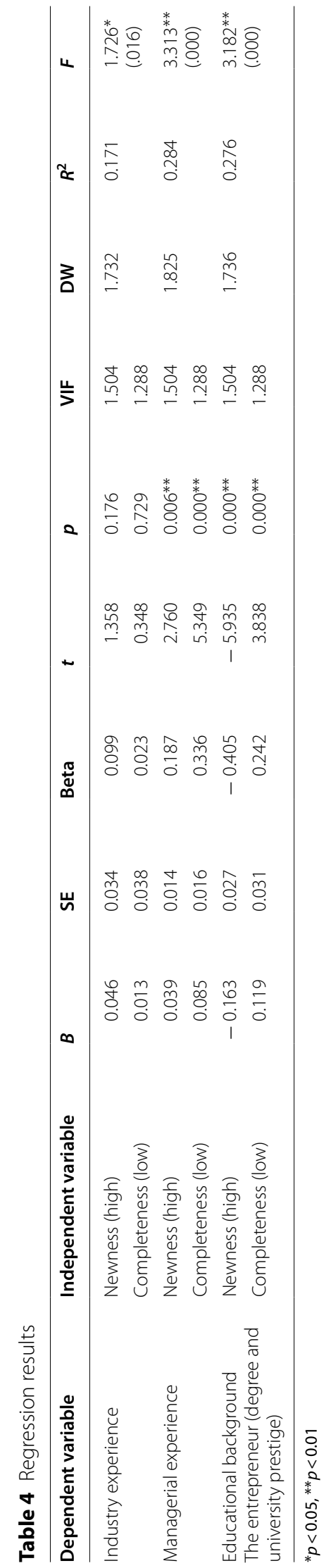


analysis, entrepreneurial experience was the least considered investment decision criterion for VCs. However, as uncertainty increases, VCs seem to give more importance to the managerial experience of entrepreneurs. Therefore, Hypothesis 2 was fully supported.

Analyzing the relationship between uncertainty and entrepreneurs' educational background showed that the newness of ventures $(t=-5.935,=0.000<0.01)$ has a significant, negative effect on the importance of entrepreneurs' degree and university prestige. However, the effect of the completeness of the products on the importance of entrepreneurs' educational background of the entrepreneurs was positive and statistically significant, so Hypothesis 3 was partially supported. These results show that VCs consider the educational background of the entrepreneurs to be more important when the products are incomplete but less important as the newness of the products increases.

Here, we summarize the test results of the hypothesis (Table 5).

\section{Conclusions}

\section{Findings of the study}

This empirical study investigates the relative importance of the criteria used in the investment decision-making processes of Korean VCs' investment decision makings by applying conjoint analysis. Thereby, the effect of uncertainties on the importance of entrepreneurs' experiences, which are the core decision criteria of VCs, is given explicit consideration. To date, very few empirical studies on VC decision criteria of VCs have been conducted due to the complexity of the work of VCs, the confidentiality of decision-making procedures, and the difficulty of accessing investment-related data. This is the first empirical study to gather a large and unique sample of VCs and thus show the relationship between uncertainty and entrepreneurial experience in VC investment decisions. The primary theoretical significance of this study is the development of a debate on the role of the diverse experience of entrepreneurs in VCs' decision making. Although entrepreneurs' experience is considered to have a positive impact on VC decision making (Zacharakis \& Meyer, 2000), this study asserts that the impact of each experience on $\mathrm{VC}$ investment decisions is different.

Table 5 Summary of hypothesis test

\begin{tabular}{|c|c|c|}
\hline Hypothesis & Test results & Means \\
\hline $\begin{array}{l}\text { The higher the uncertainty - the newer the } \\
\text { products are, and the lower the complete- } \\
\text { ness of the products, the more VCs consider } \\
\text { the industry experience of the entrepre- } \\
\text { neurs }\end{array}$ & Rejected & $\begin{array}{l}\text { Although VCs consider entrepreneur's indus- } \\
\text { try experience in investment decision, its } \\
\text { importance does not change with increasing } \\
\text { uncertainty }\end{array}$ \\
\hline $\begin{array}{l}\text { The higher the uncertainty - the newer the } \\
\text { products are, and the lower the complete- } \\
\text { ness of the products, the more VCs consider } \\
\text { the managerial experience of entrepreneurs }\end{array}$ & Supported & $\begin{array}{l}\text { VCs seem to attach more importance to the } \\
\text { managerial experience of entrepreneurs with } \\
\text { a high level of uncertainties }\end{array}$ \\
\hline $\begin{array}{l}\text { The higher the uncertainty - the newer the } \\
\text { products are, and the lower the complete- } \\
\text { ness of the products services, the more VCs } \\
\text { consider the educational background of the } \\
\text { entrepreneurs }\end{array}$ & Partially Supported & $\begin{array}{l}\text { that VCs consider the educational back- } \\
\text { ground of the entrepreneurs to be more } \\
\text { important when the products are incomplete } \\
\text { but less important as the newness of the } \\
\text { products increases }\end{array}$ \\
\hline
\end{tabular}


We identify that VCs' most important criteria for investment decisions are entrepreneurs' educational background and industry experience (Hsu, 2004). But that in an uncertain environment, where the newness of the products is high, the entrepreneur's academic background of the entrepreneur becomes less important. In contrast, VCs care more about the managerial experience when there is a high level of uncertainty. This result is in line with the results of an earlier study in which the relationship between entrepreneurs' academic achievement and firm performance is positive in a stable environment, and when uncertainty is high, the entrepreneur's academic ability is negatively related to firm performance (Hmieleski et al., 2015). Through our paper, we have improved our understanding of the relative importance of the characteristics of entrepreneurs' experience characteristics, and the factors of startups under uncertainty, which are important criteria in the decision-making of VCs.

\section{Implications and limitations}

The result of this study may have some managerial implications. Entrepreneurs without enough experience may need to recruit more members of the executive team members with managerial and industrial experience rather than focus on members with higher educational backgrounds. In fact, many startups are composed of so-called elite teams with good academic backgrounds, but in a high-uncertainty situation, the value of that academic background needs to be supplemented with members with managerial experience.

From a theoretical point of view, this study also has some implications. In the meantime, studies have been conducted on which criteria are more important in decision making of VCs, but there have been few studies that have captured the fact that the weight of each criterion can change dynamically depending on environmental changes. This article shows that the relative importance of each criterion can be changed by environmental factors, such as uncertainty, suggesting the need for further study.

The study would also be beneficial for VCs to review their decision criteria and not to be attracted by superficial aspects of entrepreneurs. Furthermore, this study conducted a process to investigate the opinions of VCs and expert groups on attributes and levels derived from previous studies and analyzed large-scale data on VCs that may be useful for following studies.

This study focuses only on the decision criteria used in the screening phase, which is the initial stage of the $\mathrm{VC}$ investment process. Therefore, the varying criteria, depending on the stage of the decision-making process (Shepherd \& Zacharakis, 1999), could also be considered. The source of uncertainties that affect the evaluation of entrepreneurial firms may vary more, although our study investigated deals mainly with the newness and completeness of the product.

The methodology used in this study also has limitations. Although the VIF value was found to be appropriate, this does not completely deny the possibility of multicollinearity, and it should be considered that the sample size limit still exists. The study suggests venue for further development. We have considered such decision criteria for VCs as entrepreneurs' industry experience, managerial experience, entrepreneurial experience, educational background, investment attraction experience, and newness and completeness of venture products. However, we have not considered market and competition. 
Characteristics, such as market size and market growth rate, and financial considerations, such as rate of return and investment payback period, surely play an important role in the investment decision and should be considered in future studies.

\section{Authors' contributions}

Conceptualization, methodology, and revision, DK; formal analysis and original draft preparation, SYL. All authors read and approved the final manuscript.

\section{Funding}

None.

\section{Availability of data and materials}

Not applicable.

\section{Declarations}

\section{Competing interests}

The authors declare that they have no competing interests.

Received: 19 July 2021 Accepted: 28 February 2022

Published online: 05 March 2022

\section{References}

Adler, P. S., \& Kwon, S. W. (2002). Social capital: Prospects for a new concept. Academy of Management Review. https://doi. org/10.5465/AMR.2002.5922314

Amit, R., Brander, J., \& Zott, C. (1998). Why do venture capital firms exist? Theory and canadian evidence. Journal of Business Venturing. https://doi.org/10.1016/S0883-9026(97)00061-X

Andrieu, G. (2013). The impact of the affiliation of venture capital firms: A survey. Journal of Economic Surveys. https://doi. org/10.1111/j.1467-6419.2011.00702.x

Audretsch, D. B., Bönte, W., \& Mahagaonkar, P. (2012). Financial signaling by innovative nascent ventures: The relevance of patents and prototypes. Research Policy, 41(8), 1407-1421.

Batjargal, B. (2003a). Internet entrepreneurship in an emerging market: Networks and performance of internet startups. Academy of Management Proceedings. https://doi.org/10.5465/ambpp.2003.13793242

Batjargal, B. (2003b). Social capital and entrepreneurial performance in Russia: A longitudinal study. Organization Studies, 24(4), 535-556.

Baum, J. A. C., \& Silverman, B. S. (2004). Picking winners or building them? Alliance, intellectual, and human capital as selection criteria in venture financing and performance of biotechnology startups. Journal of Business Venturing. https://doi.org/10.1016/S0883-9026(03)00038-7

Beim, G., \& Levesque, M. (2004). Selecting projects for venture capital funding: a multiple criteria decision approach. Whistler.

Belliveau, M. A., O'Reilly, C. A., \& Wade, J. B. (1996). Social capital at the top: Effects of social similarity and status on CEO compensation. Academy of Management Journal. https://doi.org/10.2307/257069

Berger, A. N., \& Udell, G. F. (1998). The economics of small business finance: The roles of private equity and debt markets in the financial growth cycle. Journal of Banking and Finance. https://doi.org/10.1016/S0378-4266(98)00038-7

Bhagavatula, S., Elfring, T., van Tilburg, A., \& van de Bunt, G. G. (2010). How social and human capital influence opportunity recognition and resource mobilization in India's handloom industry. Journal of Business Venturing. https://doi.org/10. 1016/j.jbusvent.2008.10.006

Birley, S., \& Norburn, D. (1987). Owners and managers: The venture 100 vs the fortune 500. Journal of Business Venturing. https://doi.org/10.1016/0883-9026(87)90026-7

Boocock, G., \& Woods, M. (1997). The evaluation criteria used by Venture capitalists: Evidence from a UK Venture fund. International Small Business Journal. https://doi.org/10.1177/0266242697161003

Calantone, R., Garcia, R., \& Dröge, C. (2003). The effects of environmental turbulence on new product development strategy planning. Journal of Product Innovation Management. https://doi.org/10.1111/1540-5885.2002003

Carayannis, E. G., \& Rakhmatullin, R. (2014). The quadruple/quintuple innovation helixes and smart specialisation strategies for sustainable and inclusive growth in Europe and beyond. Journal of the Knowledge Economy, 5(2), 212-239. https://doi.org/10.1007/S13132-014-0185-8

Cassar, G. (2014). Industry and startup experience on entrepreneur forecast performance in new firms. Journal of Business Venturing. https://doi.org/10.1016/j.jbusvent.2012.10.002

Chandler, G. N., \& Hanks, S. H. (1998). An examination of the substitutability of founders human and financial capital in emerging business ventures. Journal of Business Venturing. https://doi.org/10.1016/S0883-9026(97)00034-7

Chang, S. J. (2004). Venture capital financing, strategic alliances, and the initial public offerings of Internet startups. Journal of Business Venturing. https://doi.org/10.1016/j.jbusvent.2003.03.002

Chrisman, J. J., Bauerschmidt, A., \& Hofer, C. W. (1998). The determinants of new venture performance: An extended model. Entrepreneurship Theory and Practice. https://doi.org/10.1177/104225879802300101

Cooper, A. C., Gimeno-Gascon, F. J., \& Woo, C. Y. (1994). Initial human and financial capital as predictors of new venture performance. Journal of Business Venturing. https://doi.org/10.1016/0883-9026(94)90013-2 
Cooper, R. G., \& Kleinschmidt, E. J. (1991). New product processes at leading industrial firms. Industrial Marketing Management. https://doi.org/10.1016/0019-8501(91)90032-B

Criaco, G., Minola, T., Migliorini, P., \& Serarols-Tarrés, C. (2014). "To have and have not": Founders' human capital and university start-up survival. Journal of Technology Transfer. https://doi.org/10.1007/s10961-013-9312-0

Delmar, F., \& Shane, S. (2006). Does experience matter? The effect of founding team experience on the survival and sales of newly founded ventures. Strategic Organization, 4(September), 215-247. https://doi.org/10.1177/1476127006 066596

Dimov, D., \& Milanov, H. (2010). The interplay of need and opportunity in venture capital investment syndication. Journal of Business Venturing. https://doi.org/10.1016/j.jbusvent.2009.01.002

Drover, W., Busenitz, L., Matusik, S., Townsend, D., Anglin, A., \& Dushnitsky, G. (2017). A review and road map of entrepreneurial equity financing research: Venture capital, corporate venture capital, angel investment, crowdfunding, and accelerators. Journal of Management, 43(6), 1820-1853. https://doi.org/10.1177/0149206317690584

Eisenhardt, K. M. (1989). Making fast strategic decisions in high-velocity environments. Academy of Management Journal. https://doi.org/10.5465/256434

Elfring, T., \& Hulsink, W. (2003). Networks in entrepreneurship: The case of high-technology firms. Small Business Economics. https://doi.org/10.1023/A:1026180418357

Franke, N., Gruber, M., Harhoff, D., \& Henkel, J. (2008). Venture capitalists' evaluations of start-up teams: Trade-offs, knockout criteria, and the impact of VC experience. Entrepreneurship Theory and Practice, 32(3), 459-483. https://doi.org/10. $1111 / j .1540-6520.2008 .00236 . x$

Fried, V. H., \& Hisrich, R. D. (1994). Toward a model of venture capital investment decision making. Financial Management, 23(3), 28-37.

Gifford, S. (1992). Allocation of entrepreneurial attention. Journal of Economic Behavior and Organization. https://doi.org/ 10.1016/0167-2681(92)90038-D

Gimeno, J., Folta, T. B., Cooper, A. C., \& Woo, C. Y. (1997). Survival of the fittest? Entrepreneurial human capital and the persistence of underperforming firms. Administrative Science Quarterly. https://doi.org/10.2307/2393656

Goldenberg, J., Lehmann, D. R., \& Mazursky, D. (2001). The idea itself and the circumstances of its emergence as predictors of new product success. Management Science. https://doi.org/10.1287/mnsc.47.1.69.10670

Gompers, P. A., Gornall, W., Kaplan, S. N., \& Strebulaev, I. A. (2020). How do venture capitalists make decisions? Journal of Financial Economics, 135(1), 169-190. https://doi.org/10.1016/j.jfineco.2019.06.011

Gompers, P., \& Lerner, J. (2001). The venture capital revolution. The Journal of Economic Perspectives, 15(2), 145-168.

Hall, J., \& Hofer, C. W. (1993). Venture capitalists' decision criteria in new venture evaluation. Journal of Business Venturing. https://doi.org/10.1016/0883-9026(93)90009-T

Hmieleski, K. M., Carr, J. C., \& Baron, R. A. (2015). Integrating discovery and creation perspectives of entrepreneurial action: The relative roles of founding CEO human capital, social capital, and psychological capital in contexts of risk versus uncertainty. Strategic Entrepreneurship Journal. https://doi.org/10.1002/sej.1208

Hsu, D. H. (2004). What do entrepreneurs pay for venture capital affiliation? Journal of Finance, 59(4), 1805-1844. https:// doi.org/10.1111/j.1540-6261.2004.00680.x

Hsu, D. H. (2007). Experienced entrepreneurial founders, organizational capital, and venture capital funding. Research Policy. https://doi.org/10.1016/j.respol.2007.02.022

Hyytinen, A., Pajarinen, M., \& Rouvinen, P. (2015). Does innovativeness reduce startup survival rates? Journal of Business Venturing, 30(4), 564. https://doi.org/10.1016/j.jbusvent.2014.10.001

Karniouchina, E. V., Moore, W. L., van der Rhee, B., \& Verma, R. (2009). Issues in the use of ratings-based versus choicebased conjoint analysis in operations management research. European Journal of Operational Research. https://doi. org/10.1016/i.ejor.2008.05.029

Kirsch, D., Goldfarb, B., \& Gera, A. (2009). Form or substance: The role of business plans in venture capital decision making. Strategic Management Journal. https://doi.org/10.1002/smj.751

Kollmann, T., \& Kuckertz, A. (2010). Evaluation uncertainty of venture capitalists'investment criteria. Journal of Business Research, 63(7), 741-747. https://doi.org/10.1016/j.jbusres.2009.06.004

Lechner, C., \& Dowling, M. (2003). Firm networks: External relationships as sources for the growth and competitiveness of entrepreneurial firms. Entrepreneurship and Regional Development. https://doi.org/10.1080/08985620210159220

Lechner, C., Kirschenhofer, F., \& Dowling, M. (2015). The influence of social capital on opportunity emergence and exploitation: A comparison of portfolio and serial entrepreneurs. Journal of Innovation and Entrepreneurship, 5(1), 1-23. https://doi.org/10.1186/S13731-016-0056-6/TABLES/5

Macmillan, I. C., Siegel, R., \& Narasimha, P. N. S. (1985). Criteria used by venture capitalists to evaluate new venture proposals. Journal of Business Venturing. https://doi.org/10.1016/0883-9026(85)90011-4

Marvel, M. R. (2013). Human capital and search-based discovery: A study of high-tech entrepreneurship. Entrepreneurship: Theory and Practice. https://doi.org/10.1111/j.1540-6520.2011.00465.x

Mason, C., \& Brown, R. (2014). Entrepreneurial ecosystems and growth oriented entrepreneurship. OECD.

Mason, C., \& Stark, M. (2004). What do investors look for in a business plan? A comparison of the investment criteria of bankers, venture capitalists and business angels. International Small Business Journal. https://doi.org/10.1177/02662 42604042377

Miloud, T., Aspelund, A., \& Cabrol, M. (2012). Startup valuation by venture capitalists: An empirical study. Venture Capital: an International Journal of Entrepreneurial Finance, 14, 37-41.

Muzyka, D., Birley, S., \& Leleux, B. (1996). Trade-offs in the investment decisions of European venture capitalists. Journal of Business Venturing. https://doi.org/10.1016/0883-9026(95)00126-3

Nahapiet, J., \& Ghoshal, S. (2009). Social capital, intellectual capital, and the organizational advantage. Knowledge and Social Capital. https://doi.org/10.2307/259373

Natter, M., \& Feurstein, M. (2002). Real world performance of choice-based conjoint models. European Journal of Operational Research. https://doi.org/10.1016/S0377-2217(01)00147-3

Palmer, D., \& Barber, B. M. (2001). Challengers, elites, and owning families: A social class theory of corporate acquisitions in the 1960s. Administrative Science Quarterly. https://doi.org/10.2307/2667126 
Parker, S. C. (2009). Entrepreneurship, self-employment and the labour market. In The Oxford handbook of entrepreneurship. Oxford University Press. https://doi.org/10.1093/oxfordhb/9780199546992.003.0016

Payne, G. T., Davis, J. L., Moore, C. B., \& Bell, R. G. (2009). The deal structuring stage of the venture capitalist decision-making process: Exploring confidence and control. Journal of Small Business Management, 47(2), 154-179. https://doi. org/10.1111/j.1540-627X.2009.00266.x

Petkova, A. P., Rindova, V. P., \& Gupta, A. K. (2013). No news is bad news: Sensegiving activities, media attention, and venture capital funding of new technology organizations. Organization Science. https://doi.org/10.1287/orsc.1120.0759

Petty, J. S., \& Gruber, M. (2011). "In pursuit of the real deal": A longitudinal study of VC decision making. Journal of Business Venturing. https://doi.org/10.1016/j.jbusvent.2009.07.002

Ployhart, R., \& Moliterno, T. (2011). Emergence of the human capital resource: A multilevel model. Academy of Management Review. https://doi.org/10.5465/amr.2009.0318

Rin, M. da, Hellmann, T., \& Puri, M. (2013). A survey of venture capital research. In Handbook of the economics of finance (Vol. 2, Issue PA, pp. 573-648). Elsevier B.V. https://doi.org/10.1016/B978-0-44-453594-8.00008-2.

Robert Baum, J., Locke, E. A., \& Smith, K. G. (2001). A multidimensional model of venture growth. Academy of Management Journal. https://doi.org/10.5465/3069456

Sanchez-Famoso, V., Maseda, A., \& Iturralde, T. (2014). The role of internal social capital in organisational innovation. An empirical study of family firms. European Management Journal. https://doi.org/10.1016/j.emj.2014.04.006

Santos, E., Fernandes, C. I., Ferreira, J. J., \& Lobo, C. A. (2021). What is the impact of informal entrepreneurship on venture capital flows? Journal of the Knowledge Economy, 12(4), 2032-2049. https://doi.org/10.1007/S13132-020-00701-W/ TABLES/3

Shane, S. (2003). A general theory of entrepreneurship: The individual-opportunity nexus. In A general theory of entrepreneurship: The individual-opportunity nexus. https://doi.org/10.4337/9781781007990

Shane, S., \& Venkataraman, S. (2000). The promise of entrepreneurship as a field of research. Academy of Management Review, 25(1), 217-226. https://doi.org/10.5465/amr.2000.2791611

Shepherd, D. A., \& Zacharakis, A. (1999). Conjoint analysis: A new methodological approach for researching the decision policies of venture capitalists. Venture Capital. https://doi.org/10.1080/136910699295866

Shepherd, D. A., Zacharakis, A., \& Baron, R. A. (2003). VCs' decision processes: Evidence suggesting more experience may not always be better. Journal of Business Venturing, 18(3), 381-401. https://doi.org/10.1016/S0883-9026(02)00099-X

Siegel, D. S., \&Wessner, C. (2012). Universities and the success of entrepreneurial ventures: Evidence from the small business innovation research program. Journal of Technology Transfer. https://doi.org/10.1007/s10961-010-9186-3

Silva, J. (2004). Venture capitalists' decision-making in small equity markets: A case study using participant observation. Venture Capital. https://doi.org/10.1080/13691060410001675974

Simon, H. A. (1955). A behavioral model of rational choice. Quarterly Journal of Economics. https://doi.org/10.2307/18848 52

Singh, J. V., Tucker, D. J., \& House, R. J. (1986). Organizational legitimacy and the liability of newness. Administrative Science Quarterly. https://doi.org/10.2307/2392787

Steenkamp, J. B. E. M., \& Gielens, K. (2003). Consumer and market drivers of the trial probability of new consumer packaged goods. Journal of Consumer Research. https://doi.org/10.1086/378615

Tyebjee, T. T., \& Bruno, A. V. (1984). A model of venture capitalist investment activity. Management Science, 30(9), 1051-1066. https://doi.org/10.1287/mnsc.30.9.1051

Vinig, T. G., \& de Haan, M. (2005). How do venture capitalists screen business plans? Evidence from The Netherlands and the US. SSRN Electronic Journal. https://doi.org/10.2139/ssrn.321860

Vuong, Q. H., Do, T. H., \& Vuong, T. T. (2015). Resources, experience, and perseverance in entrepreneurs' perceived likelihood of success in an emerging economy. Journal of Innovation and Entrepreneurship, 5(1), 1-24. https://doi.org/10. 1186/S13731-016-0047-7/FIGURES/7

Wally, S., \& Baum, J. R. (1994). Personal and structural determinants of the pace of strategic decision making. Academy of Management Journal. https://doi.org/10.5465/256605

Wiersema, M. F., \& Bantel, K. A. (1992). Top management team demography and corporate strategic change. Academy of Management Journal. https://doi.org/10.5465/256474

Wiklund, J., \& Shepherd, D. A. (2008). Portfolio entrepreneurship: Habitual and novice founders, new entry, and mode of organizing. Entrepreneurship: Theory and Practice. https://doi.org/10.1111/j.1540-6520.2008.00249.x

Woods, C., Yu, H., \& Huang, H. (2020). Predicting the success of entrepreneurial campaigns in crowdfunding: A spatiotemporal approach. Journal of Innovation and Entrepreneurship, 9(1), 1-23. https://doi.org/10.1186/S13731-02000122-8/FIGURES/12

Zacharakis, A. L., \& Meyer, G. D. (2000). The potential of actuarial decision models: Can they improve the venture capital investment decision? Journal of Business Venturing. https://doi.org/10.1016/S0883-9026(98)00016-0

Zacharakis, A. L., \& Shepherd, D. A. (2001). The nature of information and overconfidence on venture capitalists' decision making. Journal of Business Venturing. https://doi.org/10.1016/S0883-9026(99)00052-X

Zacharakis, A., \& Shepherd, D. A. (2005). A non-additive decision-aid for venture capitalists' investment decisions. European Journal of Operational Research. https://doi.org/10.1016/j.ejor.2003.10.028

Zutshi, R. K., Tan, W. L., Allampalli, D. G., \& Gibbons, P. G. (1999). Singapore venture capitalists (VCs) investment evaluation criteria: A re-examination. Small Business Economics. https://doi.org/10.1023/A:1008011216414

\section{Publisher's Note}

Springer Nature remains neutral with regard to jurisdictional claims in published maps and institutional affiliations. 